\section{Tissue Culture Regeneration of a Medicinal Plant from Mexico: Piper auritum Kunth.}

\author{
Fabiola Domínguez ${ }^{1}$ \\ New Use Agriculture and Natural Plant Products Program, Rutgers University, \\ Foran Hall, 59 Dudley Road, New Brunswick, NJ 08901
}

\author{
Xavier Lozoya \\ Unidad de Investigación en Enfermedades Neurológicas, Hospital de \\ Especialidades, Centro Médico Nacional Siglo XXI, IMSS. Av. Cuauhtémoc \\ 330 Col. Doctores, México, D.F. 06720, Mexico
}

\section{James Simon \\ New Use Agriculture and Natural Plant Products Program, Rutgers University, Foran Hall, 59 Dudley Road, New Brunswick, NJ 08901 \\ Additional index words. adventitious shoot regeneration, organogenesis, Piper auritum, yerba santa}

\begin{abstract}
An efficient whole plant regeneration method from callus cultures of Piper auritum was achieved through organogenesis derived from leaf tissue. Proliferating callus and shoot cultures derived from leaf tissue explants placed on Murashige and Skoog (MS) medium supplemented with $2.0 \mathrm{mg} \cdot \mathrm{L}^{-1} 2$, 4-dichlorophenoxyacetic acid $(2,4-\mathrm{D})$ plus 1.5 $\mathrm{mg} \cdot \mathrm{L}^{-1}$ kinetin. Optimum combination of hormones $\left(\mathrm{mg} \cdot \mathrm{L}^{-1}\right)$ for shoot induction was 0.5 2,4-D : $1.5 \mathrm{mg} \cdot \mathrm{L}^{-1}$ kinetin (by volume), that resulted in a high rooting rate (49.6 shoots per explant). All of the plants elongated when using a medium consisting of $0.1 \mathrm{mg} \cdot \mathrm{L}^{-1} \mathbf{2 , 4}-\mathrm{D}$ plus $1 \mathrm{mg} \cdot \mathrm{L}^{-1}$ kinetin. Elongated shoots were successfully rooted $(100 \%)$ on half-strength MS medium supplemented with $2.0 \mathrm{mg} \cdot \mathrm{L}^{-1}$ indole-3-acetic acid. All plantlets survived to the growing conditions of a greenhouse. This study demonstrates that leaf tissue of $P$. auritum is competent for adventitious shoot regeneration and establishes an efficient and useful protocol for the multiplication and conservation of $\boldsymbol{P}$. autirum for further investigation of its medicinally active constituents.
\end{abstract}

The genus Piper, with $>1,000$ species, is widely distributed in the tropical and subtropical regions of the world and is used in a variety of ways (Kirtikar and Basu, 1993; Parmar et al., 1997). While attention in Piper spp. focuses predominantly on $P$. nigrum $\mathrm{L}$, from which commercial black pepper of commerce is obtained for used as spice and condiment, Piper spp. contain a wide range of other natural products with pharmacological activity. Kava Kava from P. methysticum G. Furst, has received considerable worldwide interest due to its potential use to treat anxiety comparable to treatment by synthetic antianxiety drugs such as benzodiazepines (i.e., valium) (Davies and Drew, 1992). Piper amalago L. reduced the blood pressure what could be a result of its bioactive compounds found to be identical to dopamine (Durand et al., 1962).

Received for publication 5 Aug. 2005. Accepted for publication 3 Nov. 2005. This research was supported by the funding from the New Use Agriculture and Natural Products Program, the New Jersey Agricultural Experiment Station and Cook College, Rutgers University. We acknowledge the funding by Instituto Mexicano del Seguro Social (IMSS) from México sponsored the senior author's graduate studies in the U.S. We also thank Jeremy Kapteyn, Diego Moreno, and Eduardo Aranda for their assistance during this study and review of this manuscript.

${ }^{1}$ To whom reprint requests should be sent; e-mail irmafabiola@yahoo.com.
The aromatic volatile oil of $P$. angustifolium Lam. has been reported to exhibit bacteriostatic and fungistatic activities against Trichophyton mentagrophytes, Pseudomona aeruginosa, Candida albicans and Aspergillus fumigatus (Tirillini et al., 1996). Piper canium L. exhibited antibacterial activity against Gram-positive bacteria Bacillus cereus, Staphylococcus aureus, and Streptococcus pneumoniae (Setzer et al., 1999).

Mexico has several Piper species, including $P$. auritum Kunth locally known as yerba santa among the most important. This is an aromatic-shrub species, 2 to $5 \mathrm{~m}$ in height; characterized by oval to ovate-elliptical leaves. Leaves and stems are widely used due to its highly valued unique flavor. Fresh or air dried, the plant is routinely consumed as a seasoning in foods such as curing meat and fish. The plant is used by the indigenous tribes to catch fish during the dry season (Mason and Mason, 1987). Although P. auritum has ethnomedicinal antecedents for traditional use. No pharmacological studies have been reported (Alonso, 1999). Phytochemical studies of $P$. auritum demonstrated that this specie contains a number of natural products responsible for its pungency and bioactivity. Piperine, the same compound in black pepper responsible for its pungency, is also found in yerba santa. Yerba santa has been shown to exhibit a cytoprotective effect in oral administration and effectively suppressed lung cancer (Selvendiran et al., 2003). Other compounds found in this plant, but also found in a wide range of other species as well as medicinal plants include myristicin and aporphine type of alkaloids (Ampofo et al., 1987; Haensel et al., 1975; Nair et al., 1989; Parmar et al., 1997). In view of the importance of studying the pharmacological actions of this plant, a series of studies were conducted to first establish a propagation system for this species as the plant is difficult to collect, identify and vegetatively propagate (Trelease, 1950). Both dioeciously and hermaphrodite forms occur in Piper, and cultivated forms are clonally propagated through cuttings. Tissue culture techniques may play an important role in clonal propagation, germ plasm conservation and plant improvement of $P$. auritum. The establishment of in vitro cultures of Piper species ( $P$. nigrum and $P$. longum L.) has been slow and made difficult by the high incidence of bacterial contamination reported as high as $90 \%$ of primary cultures (Bath et al., 1992). Even healthy cultures show bacterial growth following subculture in different species of Piper (Bath etal., 1995; Fitchet, 1990; Mathews and Rao, 1984; Philip et al., 1992). There are no reports on the regeneration $P$. auritum using tissue culture, and as consequently species remains difficult to vegetatively propagate. Given our interest in studying the bioactive phytochemicals in this species under controlled conditions, here we aimed to determine the competency in using leaf tissue of $P$. auritum for regeneration and to develop an in vitro regeneration method using leaf explants.

\section{Materials and Methods}

Plantmaterial and sterilization procedures. Young leaves of $P$. auritum were collected from 3-year-old plants grown in Cocoyoc Morelos, Mexico. Botanical identification and authentication was conducted in concert with the Herbarium of the Instituto Mexicano del Seguro Social (IMSS) in Mexico City, where voucher specimens were deposited (voucher number 14609) at herbarium IMSS. Whole mature leaves were manually removed from the parent vines. Freshly harvested leaves were surface sterilized by gently placing the leaf into washing vessel $(1 \mathrm{~L})$, which contained a solution of deionized water with the detergent Extran 5\% (by volume) (Labo Clean, Inc, Puebla, Puebla) for 5 to $10 \mathrm{~min}$. After this initial wash, whole leaves $(5 \times 5$ $\mathrm{cm}$ ) were disinfected with $75 \%$ Ethanol for $1 \mathrm{~min}$, followed by $3 \%(\mathrm{w} / \mathrm{v})$ commercial bleach (containing 1\% sodium hypochlorite) with occasional agitation. As last step, leaves were washed in sterile water three times for five minutes under aseptic conditions in a laminar flow hood. After, the leaf was washed in a 5\% PPM (Plant Cell Technology, Inc.) solution $(\mathrm{w} / \mathrm{v})$ for $5 \mathrm{~min}$.

Culture media and incubation conditions. For callus and shoot initiation the leaf margins were removed along with the tip and basal portions. Leaf sections with central nerves (1 $\times 1 \mathrm{~cm}$ ) were placed with the axial surface in contact with the callus induction media and 
Table 1. Effect of different combinations of the auxin 2,4-dichlorophenoxyacetic acid (2,4-D) and the cytokinen kinetin on shoot regeneration from callus cultures of Piper auritum after 4 weeks of culture.

\begin{tabular}{lcc}
\hline $\begin{array}{l}2,4-\mathrm{D}: \text { kinetin } \\
\left(\mathrm{mg} \cdot \mathrm{L}^{-1}\right)\end{array}$ & $\begin{array}{c}\text { Percent of callus } \\
\text { with shoot initiation }\end{array}$ & $\begin{array}{c}\text { Avg of shoots } \\
(\text { mean } \pm \mathrm{SD})\end{array}$ \\
\hline $0.0: 0.5$ & $0(0 / 50)$ & 0.0 \\
$0.5: 0.5$ & $0(0 / 50)$ & 0.0 \\
$0.5: 1.5$ & $72(36 / 50)$ & $49.6 \pm 1.0$ \\
$0.5: 2.0$ & $45(22 / 50)$ & $23.5 \pm 1.8$ \\
$0.5: 1.0$ & $38(19 / 50)$ & $23.8 \pm 2.0$ \\
$1.0: 1.5$ & $0(0 / 50)$ & 0 \\
$1.0: 2.0$ & $30(15 / 50)$ & $3.8 \pm 1.0$ \\
$1.0: 1.0$ & $1(10 / 49)$ & $18.5 \pm 1.5$ \\
$2.0: 0.5$ & $10(05 / 50)$ & $9.0 \pm 2.0$ \\
$2.0: 1.0$ & $16(08 / 50)$ & $12.8 \pm 2.2$ \\
$2.0: 1.5$ & $20(10 / 50)$ & $5.2 \pm 1.1$ \\
\hline
\end{tabular}

replicated three times. The nutrient medium consisted of full strength Murashige and Skoog (MS) supplemented with 3\% sucrose, 100 $\mathrm{mg} \cdot \mathrm{L}^{-1}$ myo-inositol, and $1 \mathrm{mg} \cdot \mathrm{L}^{-1}$ of charcoal, with different combinations of indole-3-acetic acid (IAA), naphthalene acetic acid (NAA), or 2,4-dichlorophenoxyacetic acid (2,4-D) $\left(0,0.5,1.0\right.$, or $\left.2.0 \mathrm{mg} \cdot \mathrm{L}^{-1}\right)$ plus kinetin $(0.5$, $1.0,1.5$ or $\left.2 \mathrm{mg} \cdot \mathrm{L}^{-1}\right)$. This medium was solidified with $0.26 \%$ phytagel (Sigma-Aldrich Ltd, Co); the $\mathrm{pH}$ was adjusted to 5.7 and the medium autoclaved at $1 \mathrm{~kg} \cdot \mathrm{cm}^{-2}$ for $15 \mathrm{~min}$ at $120{ }^{\circ} \mathrm{C}$. The callus cultures were maintained in glass vessels in a growth room culture at 25 $\pm 2{ }^{\circ} \mathrm{C}$ with a daily photoperiod of $16 \mathrm{~h}(25$ $\mu \mathrm{mol} \cdot \mathrm{m}^{-2} \cdot \mathrm{s}^{-1}$ from cool-white Westinghouse fluorescent lamps). Callus cultures were maintained by subculturing every 2 weeks on a fresh medium containing $2.0 \mathrm{mg} \cdot \mathrm{L}^{-1} 2,4-\mathrm{D}$ and $1.0 \mathrm{mg} \cdot \mathrm{L}^{-1}$ kinetin.

Plant regeneration. Calli, which had undergone eight subcultures, were used for the plant regeneration experiment. Murashige and Skoog media supplemented with various combinations of growth regulators were evaluated for shoot induction (Table 1) and subsequent shoot elongation (Table 2). Three callus explants were tested for each treatment media for shoot induction with replicated. Shoots of $5 \mathrm{~cm}$ were obtained after 4 weeks. The number of shoots initials per callus was recorded in five responding calli. The shoot length and number of nodes per shoot were recorded from 12 replicate cultures in each treatment.

The rooting was tested with different combinations of IAA from 0 to $2 \mathrm{mg} \cdot \mathrm{L}^{-1}$ in MS media supplemented with $3 \%$ sucrose, $100 \mathrm{mg} \cdot \mathrm{L}^{-1} \mathrm{myo}$-inositol, and $1 \mathrm{mg} \cdot \mathrm{L}^{-1}$ of charcoal.

After 4 weeks, rooted plantlets were washed free of the medium and transferred to potting medium (PRO-Mix BX, Premier Co., Quakertown, Pa.) maintained during 4 weeks under high humidity in a mist chamber in the greenhouse. Then plants were transferred to a mist chamber and transferred to a greenhouse under growing conditions supplemented with a 16-h photoperiod of $85 \mu \mathrm{mol} \cdot \mathrm{m}^{-2} \cdot \mathrm{s}^{-1}$ of at the New Jersey Agricultural Experiment Station Research Greenhouse. Rutgers University, New Brunswick, N.J. Successful whole plant regeneration was considered if plants grew phenotypically normal. Morphogenic response
Table 2. Effect of cytokinins on shoot elongation and growth of Piper auritum cultured on Murashige and Skoog (MS) medium with $0.1 \mathrm{mg} \cdot \mathrm{L}^{-1} 2,4$ dichlorophenoxyacetic acid (2,4-D).

\begin{tabular}{lcc}
\hline $\begin{array}{l}\text { Kinetin } \\
\left(\mathrm{mg} \cdot \mathrm{L}^{-1}\right)\end{array}$ & $\begin{array}{c}\text { Shoot length }(\mathrm{cm}) \\
(\text { mean } \pm \mathrm{SD})\end{array}$ & $\begin{array}{c}\text { Avg of nodes } \\
(\text { mean } \pm \mathrm{SD})\end{array}$ \\
\hline 0 & 0 & 0 \\
0.2 & $2.7 \pm 1.8 \mathrm{~b}^{\mathrm{z}}$ & $2.3 \pm 0.8 \mathrm{~b}$ \\
0.4 & $4.0 \pm 0.6 \mathrm{~d}$ & $3.4 \pm 1.2 \mathrm{c}$ \\
0.6 & $4.6 \pm 1.0 \mathrm{de}$ & $3.5 \pm 1.5 \mathrm{c}$ \\
0.8 & $5.2 \pm 0.4 \mathrm{e}$ & $4.4 \pm 0.8 \mathrm{~d}$ \\
1.0 & $7.3 \pm 0.8 \mathrm{f}$ & $6.8 \pm 1.3 \mathrm{e}$ \\
1.5 & $1.1 \pm 0.4 \mathrm{a}$ & $1.4 \pm 0.7 \mathrm{a}$ \\
\hline
\end{tabular}

${ }^{\mathrm{z}}$ Means followed by the same letters are not significantly different at $p \leq 0.05$ according to Duncan's multiple range test.

of callus cultures was also studied using 50 replications per treatment.

Data were analyzed by one-way ANOVA to test for statistical significance; a post hoc Turkey's and Schaffe's multiple range tests were applied to averages significance was set at $P<0.01$ (Downy and Wearden, 1983) using SPSS software (Statistical Product and Service Solution, 2004)

\section{Results and Discussion}

Establishment of in vitro cultures using plant preservative mixture (PPM) in the medium of $P$. auritum was rapid and bacterial contaminations were observed in just $30 \%$ of primary cultures. Endogenous bacterial contamination causing severe setback to in vitro establishment of Piper ( $P$. nigrum and $P$. longum) has been reported (Mathews and Rao, 1984). Repeated surface sterilization has been shown to delay the onset of bacterial growth but not eliminate the contamination (Fitchet, 1990; Philip et al., 1992). The lowered bacterial contamination in our studies may be attributed to careful excision and surface sterilization of newly emerging shoots with PPM and repeating the surface sterilization on the original explants.

All explants produced some callus at the cut ends in nearly all treatments. Initially, callus induction was readily obtained and was observed around the nodal ring after 15 to $20 \mathrm{~d}$. The rate of callus induction varied depending on the combination of applied growth regula-
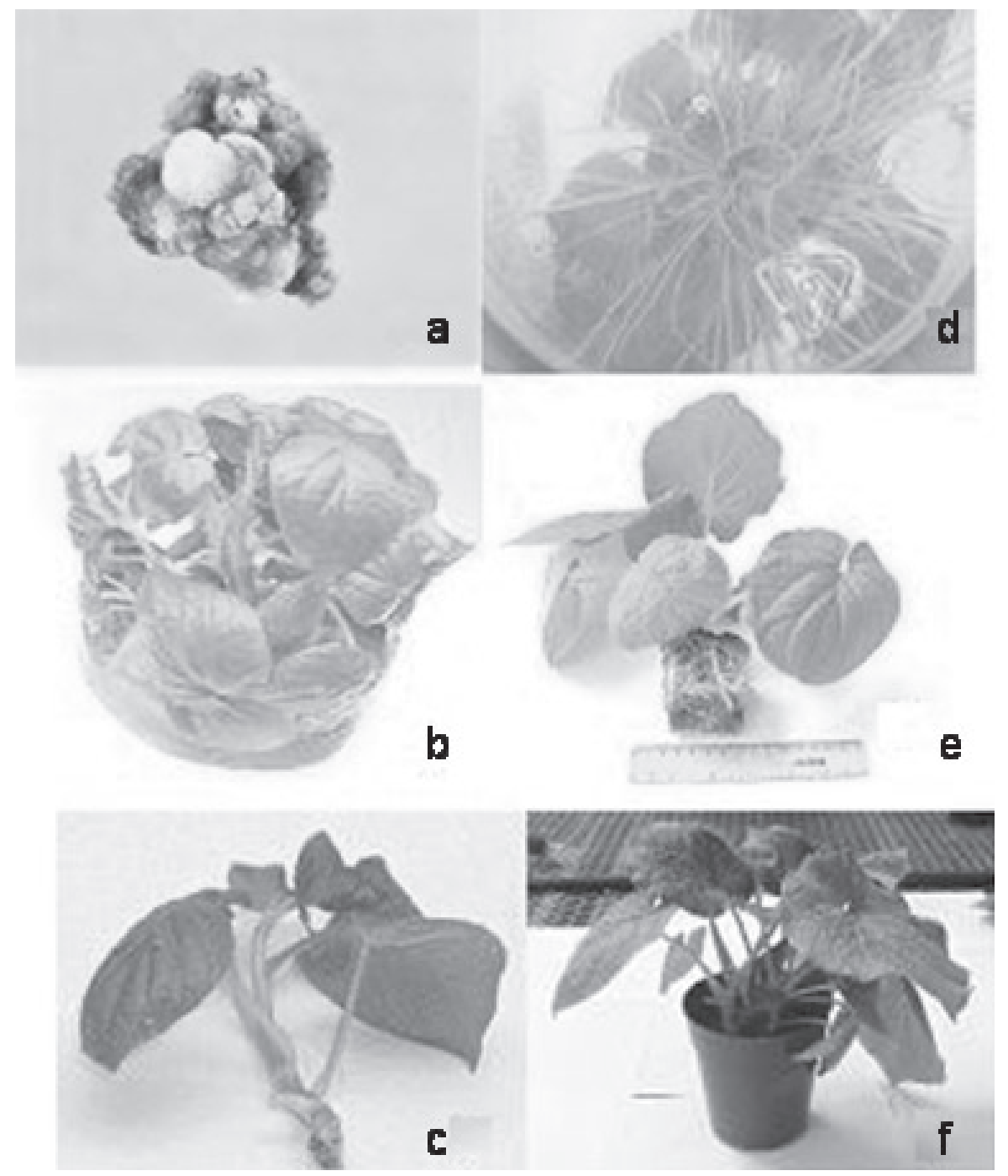

Fig. 1. Plant regeneration from callus cultures of Piper auritum on Murashige and Skoog (MS) medium supplemented with various growts regulators $\left(\mathrm{mg} \cdot \mathrm{L}^{-1}\right)$. (A) Green callus $=2.0$ 2,4-dichlorophenoxyacetic acid (2,4-D) +1.0 kinetin. (B) Shoot organogenesis $=0.52,4-\mathrm{D}+1.5$ kinetin). (C) Shoot elongation $=$ kinetin 0.6. (D) Rooted shoots $=2.0$ indole-3-acetic acid (IAA). (E and F) Regenerated plants established in soil. 
Table 3. Rooting of in vitro regenerated shoots and percent survival of regenerated plantlets of Piper auritum under greenhouse conditions.

\begin{tabular}{lccc}
\hline $\begin{array}{l}\text { Indole-3-acetic acid (IAA) } \\
\left(\mathrm{mg} \cdot \mathrm{L}^{-1}\right)\end{array}$ & $\begin{array}{c}\text { Roots } \\
(\text { no. })^{\mathrm{z}}\end{array}$ & $\begin{array}{c}\text { Rooting } \\
(\%)^{\mathrm{y}}\end{array}$ & $\begin{array}{c}\text { Survival in } \\
\text { greenhouse }(\%)^{\mathrm{x}}\end{array}$ \\
\hline 0 & 0 & 0 & --- \\
0.5 & $0.24 \pm 0.11$ & 80 & 90 \\
0.8 & $1.20 \pm 0.99^{*}$ & 98 & 93 \\
1.0 & $1.76 \pm 1.00^{*}$ & 97 & 98 \\
1.5 & $2.28 \pm 0.61^{*}$ & 99 & 100 \\
2.0 & $3.44 \pm 0.76^{*}$ & 100 & 100 \\
\hline
\end{tabular}

${ }^{\mathrm{z}}$ Data represents mean values $\pm \mathrm{SD}(\mathrm{ANOVA}, P<0.001)$ of three replications per treatment.

${ }^{y}$ Root number after 4 weeks of IAA treatments

xPercentage of survival of regenerated plantlets transferred into potting media and grown for 4 weeks under controlled greenhouse conditions.

*All means were significantly different to the treatment IAA $0.5 \mathrm{mg} \cdot \mathrm{L}^{-1} ; p<0.01$ according to Turkey's (Q $\left.{ }_{0.05},{ }_{245}=0.42\right)$ and Schaffe's $\left(Q_{0.05}{ }_{245}=0.76\right)$ multiple range tests.

tors. Media containing IAA and NAA resulted in a softer, watery callus, which turned brown following subculture. Inclusion of $2 \mathrm{mg} \cdot \mathrm{L}^{-1}$ 2,4-D yielded a harder and greener callus. Fast growing, friable, yellow-green callus was obtained in the treatment containing $1.5 \mathrm{mg} \cdot \mathrm{L}^{-1}$ kinetin and $2.0 \mathrm{mg} \cdot \mathrm{L}^{-1} 2$, 4-D (Fig. 1A). The green callus had morphogenic competence for regeneration and we only subcultured these calluses for further studies. The optimum growth regulator combination for shoot bud differentiation in P. auritum (Table 1) callus was found to be $0.52,4-\mathrm{D}: 1.5 \mathrm{kinetin}\left(\mathrm{mg} \cdot \mathrm{L}^{-1}\right)$ producing $>70 \%$ of primordial shoots were produced (Fig. 1B). Also, different concentrations of NAA and 2ip were tested but failed to elongate (data not shown).

Initial shoots induced on the combination $\left(\mathrm{mg} \cdot \mathrm{L}^{-1}\right) 0.5$ 2,4-D : 1.5 kinetin failed to elongate. Those plants were transferred to different media containing lower levels of growth regulators (Table 2). Among the treatments tested, medium with $0.1 \mathrm{mg} \cdot \mathrm{L}^{-1} 2,4-\mathrm{D}$ and $1 \mathrm{mg} \cdot \mathrm{L}^{-1}$ kinetin yield better elongation (Fig. $1 \mathrm{C})$. Both the maximum mean shoot length and the maximum number of nodes per shoot were obtained on this medium.

These results are in agreement with previous findings where levels of cytokinins promoted shoot bud multiplication but prevented shoot elongation (Bhatt and Dhar, 2004). Root induction and development was achieved with $100 \%$ efficiency on half-strength MS medium containing $2.0 \mathrm{mg} \cdot \mathrm{L}^{-1} \mathrm{IAA}\left(\mathrm{F}_{0.05}, 4=108.93, p\right.$ $<0.01$; Turkey's and Schaffe's multiple range tests, highly significant for this treatment at $p<$ 0.01 ; Table 3 ). Rooted plants were established in soil media in a greenhouse with $100 \%$ success (Fig. 1D and F).

The results of our work demonstrated that leaf tissue of $P$. auritum are competent for adventitious shoot organogenesis and provides a regeneration method using a convenient and abundant tissue source. Unlike many other Piper spp., $P$. auritum is easily amenable to cell culture techniques and the significant problems associated with bacterial contamination in other Piper spp. were easily controlled using the techniques described above. This regeneration technique will facilitate the application of biotechnology for the further study and improvement of this species and medicinal plant.

The useful $P$. auritum regeneration may be attributed to the proper selection of explant sourcing and the identification of the right growth medium to support competence leading to a very useful source of plant material for pharmacological or phytomedicinal screening and applications.

\section{Literature Cited}

Alonso, J. 1999. Tratado de fitomedicina, p. 649. Isis, Buenos Aires, Argentina.

Ampofo, S., V. Roussis, and D. Wiemer. 1987. New prenylated phenolics from Piper auritum. Phytochemistry 8:2367-2370.

Bath, S., A. Kackar, and K. Chandel. 1992. Plant regeneration from callus of Piper longum L. by organogenesis. Plant Cell Rpt. 11:525-528.

Bath, S., K. Chandel, and A. Malik. 1995. Plant regeneration from various explants of cultivated Piper species. Plant Cell Rpt. 14:398-402.

Bhatt, I. and U. Dhar. 2004. Factors controlling micropropagation of Myrica esculenta buch.-Ham.
Ex D. Don: A high value wild edible of Kumaun Himalaya. Afr. J. Biotechnol. 3:534-540

Davies, L. and C. Drew. 1992. Kava pyrones and resin: Studies on GABAa, GABAb and benzodiacepine binding sites in rodent brain. Pharmacol. Toxicol. 71:120-6.

Downy, A. and S. Wearden. 1983. Statics for research, p. 243. Wiley, New York.

Durand, E., E. Ellington, P. Feng, J. Haynes, K. Magnus, and N. Philip. 1962. Simple hypotensive and hypertensive principles from some West Indian medicinal plants. J. Pharm. Pharmacol. 6:562-563.

Fitchet, M. 1990. Establishment of Piper nigrum in vitro. Acta Hort. 275:285-291.

Haensel, R., Leuschke, A and A. Gómez-Pompa. 1975. Aporphine-type alkaloids from Piper auritum. Lloydia 6:529-30.

Kirtikar, K and B. Basu. 1993. Indian medicinal plants periodical experts book agency, p. 1957. Indian Ac Press, New Delhi.

Mason, C. and B. Mason. 1987. A handbook of Mexican roadside flora, p. 292. Univ. Ariz. Press Tucson

Mathews, H. and P. Rao. 1984. In vitro responses of black pepper (Piper nigrum). Curr. Sci. 53:183-186.

Murashige, T. and F. Skoog. 1962. A revised medium for rapid growth and bioassays with tobacco tissue cultures. Physiol Plant 15:473-497.

Nair, M., J. Sommerville, and B. Burke. 1989. Phenylpropenoids from roots of Piper auritum. Phytochemistry 2:654-655.

Parmar, V., S. Jain, K. Bisht, R. Jain, P. Taneja, A. Jha, O. Tyagi, A. Prasad, J. Wengel, C. Olsen, and P. Boll. 1997. Phytochemistry of the genus Piper. Phytochemistry 46:597-673.

Philip, V., D. Joshep, G. Triggs, and N. Dickison. 1992. Micropropagation of black pepper (Piper nigrum Linn) through shoot tip cultures. Plant Cell Rpt. 12:41-44.

Selvendiran, K., J. Prince, B. Krishnan, and D. Sakthisekaran. 2003. Cytoprotective effect of piperine against benzo $[\propto]$ pyrene induced lung cancer with reference to lipid peroxidation and antioxidant system in Swiss albino mice. Fitoterapia 74:109-115.

Setzer, W., M. Setzer, R. Bates, P. Nakkiew, B. Jackes, L. Chen, M. McFerrín, and E. Meehan. 1999. Antibacterial hydroxycinnamic esters from Piper canium from Paluma, North Queensland, Australia. The crystal and molecular structure of (+)-bornyl coumarate. Planta Med. 65:747-749.

Tirillini, B., E. Velasquez, and R. Pellegrino. 1996. Chemical composition and antimicrobial activity of essential oil of Piper angustifolium. Planta Med. 4:372-373.

Trelease, W. 1950. The Piperaceae of northern South America, p. 133. Univ. Ill. Press, Urbana. 